\title{
Why Does SARS-CoV-2 Infection Induce Autoantibody Production?
}

\author{
Ales Macela and Klara Kubelkova * \\ Department of Molecular Pathology and Biology, Faculty of Military Health Sciences, University of Defence, \\ Trebesska 1575, 50001 Hradec Kralove, Czech Republic; ales.macela@unob.cz \\ * Correspondence: klara.kubelkova@unob.cz
}

check for updates

Citation: Macela, A.; Kubelkova, K. Why Does SARS-CoV-2 Infection Induce Autoantibody Production? Pathogens 2021, 10, 380. https:// doi.org/10.3390/pathogens 10030380

Academic Editor: Lisa Gralinski

Received: 28 February 2021

Accepted: 19 March 2021

Published: 22 March 2021

Publisher's Note: MDPI stays neutral with regard to jurisdictional claims in published maps and institutional affiliations.

Copyright: (c) 2021 by the authors. Licensee MDPI, Basel, Switzerland. This article is an open access article distributed under the terms and conditions of the Creative Commons Attribution (CC BY) license (https:// creativecommons.org/licenses/by/ $4.0 /)$.

\begin{abstract}
SARS-CoV-2 infection induces the production of autoantibodies, which is significantly associated with complications during hospitalization and a more severe prognosis in COVID-19 patients. Such a response of the patient's immune system may reflect (1) the dysregulation of the immune response or (2) it may be an attempt to regulate itself in situations where the non-infectious self poses a greater threat than the infectious non-self. Of significance may be the primary virus-host cell interaction where the surface-bound ACE2 ectoenzyme plays a critical role. Here, we present a brief analysis of recent findings concerning the immune recognition of SARS-CoV-2, which, we believe, favors the second possibility as the underlying reason for the production of autoantibodies during COVID-19.
\end{abstract}

Keywords: COVID-19; SARS-CoV-2; autoantibodies; innate immune recognition; ACE2 signaling

The ongoing COVID-19 pandemic reopens the question of why infections induce the production of natural antibodies (NAbs) having the character of autoantibodies (AAbs). These originally were referred to as natural AAbs. According to clinical data, patients infected with severe acute respiratory syndrome coronavirus 2 (SARS-CoV-2) have a limited spectrum of AAbs specificities, among them anti-phospholipid, anti-interferon alpha and omega (both are type I interferons), anti-interleukins, anti-chemokines, anti-52 kDa SSA/Ro and 60 kDa SSA/Ro ribonucleoproteins, and anti-cardiolipin AAbs [1-6]. The presence and level of AAbs frequently detected in patients with COVID-19 are significantly associated with complications during hospitalization and more severe prognoses [7]. The authors of this contribution note that association of AAbs with an unfavorable prognosis possibly reflects a pathogenetic role of immune dysregulation [7]. The arguments for this assertion were based on the clinical data of COVID-19 patients, spectrum of autoantibody specificities, and the correlation between autoantibody-positive patients vs. autoantibodynegative patients that are presented by Pascolini et al. [7]. An analogous argument was also given in the publication by Tay et al. [8].

It is generally accepted, however, that the production of NAbs targeting autoantigens in healthy individuals is an evolutionarily fixed natural process that first arose in cartilaginous fish. Their pentameric IgM is thought to act as an innate-like, T-independent first-line defender until an antigen-specific response can be developed [9].

NAbs having the character of AAbs have been studied since the 1940s [10-13], and their name was chosen because they are produced at birth in the absence of exposure to foreign antigens. The main characteristics of NAbs, the majority of which are of the IgM isotype, are polyreactive with low binding affinity but high avidity. It became clear very early, however, that, along with the spontaneous production of NAbs, infections of animals by microbial agents induce the production of antibodies reacting with the host's molecular components [14-16]. This situation, in humans, is clearly demonstrated following SARS-CoV-2 infection. 
We have tested the production of NAbs using a murine model during very early infection with virulent Francisella tularensis subsp. holarctica, strain FSC 200 [17]. The majority of such infections induced the production of antibody clones during 12, 24, and $48 \mathrm{~h}$ post-infection, reacting with bacterial proteins having orthologs or analogs in eukaryotic cells. These were predominantly of the IgM isotype, but IgG3 and IgA isotypes were also identified. The production kinetics and half-life in the sera of infected mice varied for individual antibody specificities. Generally, we can state that the production of individual antibody specificities during very early intervals post-infection (up to $48 \mathrm{~h}$ ) were temporary. The composition of the antibody clones was specific at all intervals tested. Some of the specificities produced during this innate, T-independent phase of immune response were already detected during the adaptive phase of immune response to F. tularensis infection [18-22]. Thus, the characteristics of such a humoral response to infection allowed us to denominate these early produced antibodies as infection-induced NAbs, some of which are autoreactive.

We therefore assume that NAbs having the character of AAbs can be divided into three groups according to their origins and kinetics. The first consists of NAbs originating from B1 cells located in the spleen, and possibly in the bone marrow, and their production is independent of the presence of gut microbiota. These cells constitute the largest number of spontaneously IgM-secreting cells under so-called naïve conditions. The NAbs produced by these B1 cells represent real, non-antigen-induced NAbs targeting housekeeping functions, including the binding of entities expressing dominant molecular microbial traits, such as lipopolysaccharide. The second group consists of NAbs produced by B1a cells in pleural and peritoneal cavities and characterized as responder cells [23]. We denoted these as infection-induced NAbs. These NAbs represent the real first line of defense, which can be associated with the needs of the classical complement activation pathway. Cooperation between NAbs and complement system components is needed, in some situations, for the internalization of microbes into phagocytes acting as antigen-presenting cells, and it is crucial for deciding the pathogen's intracellular fate, and, subsequently, to creating signals for the induction of adaptive immune response, as in the case of our Francisella model [24-26]. The third group of NAbs, targeting autoantigens, is produced during the phase of adaptive immunity on the basis of so-called trained immunity, which was defined as innate immune memory [27-29]. Regulation of immune processes at the phase of the adaptive immune response seems to be the dominant role of this third group of NAbs. The incorrectly processed induction and regulation of adaptive immunity by innate immune mechanisms can contribute to a chronic hyper-inflammatory state or the inability to maintain homeostasis, both of which may result in tissue damage and organ failure. Although the human B1 cells and their subtypes are not precisely defined phenotypically $[30,31]$, it is likely that the model of NAbs categorization described above can be, with certain probability, applied to humans. In the literature, the clinical severity of COVID-19 and the presence of serum AAbs are generally thought to be related as a consequence of immune dysregulation. Let us nevertheless take a closer look at this issue.

Angiotensin-converting enzyme 2 (ACE2) has been identified as the receptor for SARS$\mathrm{CoV}-2$, and it is vital for the viral entry into the host cells [32]. Initial interaction between viral S-protein and extracellular domains of the transmembrane ACE2 proteins counteracts the conversion of angiotensin II (Ang2) to angiotensin 1-7 (Ang1-7), which opposes the action of Ang1-7 realized through MasR, a G protein-coupled receptor. This leads to an increase of Ang2 level and shifts anti-inflammatory action of Ang1-7 to proinflammatory response brought about by Ang2 at the AT1 receptor. At this point, however, internalization of the ACE2-SARS-CoV-2 complex and activation of AT1 receptor by an elevated level of Ang2 initiates increased activity of ADAM17 (disintegrin and metalloproteinase 17), which mediates the proteolytic cleavage of surface ACE2 and enables it to counteract the Ang2 proinflammatory action [33-35]. ACE2, as an ectoenzyme, signals, using its circulating peptide targets, components of the renin-angiotensin signaling (RES) pathway. Misregulation of RES might be the reason why, during early stages of infection, SARS-CoV- 
2 behaves as if it is invisible to the innate immune system and initiates pathophysiological changes in the host tissues. The proinflammatory activity of Ang2 is certainly projected into the bystander cells, which are not infected by the virus, and, in such a manner, are also "instructed" to participate in the proinflammatory action together with the infected cells themselves. This signaling scheme might prolong the virus recognition, on the one hand, and on the other hand, intensify the innate response of cells inside the tissues. The relatively long lag phase enables establishing an innate aggressive inflammatory response known as cytokine storm [36-38] with the presence of serum AAbs in severe and critical cases of COVID-19 [4]. Clinically, these patients have acute respiratory distress syndrome, frequently acute cardiac injury, acute kidney injury, and even multi-organ dysfunction with such common complications as coagulopathy and thrombocytopenia [39].

The interaction of SARS-CoV-2 with the ACE2 receptor using the extracellular signaling pathways might be a source of the virus stealth phenotype. The recognition of the virus by ACE2 does not necessarily constitute real innate immune recognition, which might be realized by cytosolic pattern recognition receptors [40]. The SARS-CoV-2 genomic and subgenomic transcripts have been identified in endoplasmic reticulum membranes, mitochondrial membranes and matrix, and in nucleolus, where they potentially hijack the host cell's machinery and modulate the activation of the host's cell signaling pathways [41-43]. The SARS-CoV-2 open reading frames' manipulation of mitochondria can induce the release of mitochondrial DNA into cytosol, activate the cytosolic pattern recognition receptors and NLRP3 inflammasome [44], or initiate cell damage by oxidative stress [45,46]. Furthermore, as a consequence of SARS-CoV-2's intensive replication in infected cells and manipulation of their functional and phenotypic potential, the infected cells die and release their molecular components into the surrounding tissue. Finally, between the SARS-CoV-2 and human proteins, there are some protein epitope similarities, so-called molecular mimicry [47-49]. However, the immune response to proteins having epitopes common to both SARS-CoV-2 and human proteins is, according to current knowledge, more a matter of activated T cells rather than a T-cell independent B cell response [50]. All these events together create a deadly cocktail of signals for the immune system.

Molecular and functional characteristics of interactions between SARS-CoV-2 and the host cell generate significant immunogenic signals known as Danger-associated molecular patterns that originate from our cells along with the Pathogen-associated molecular patterns of the virus. Both types of signals initiate the innate immune recognition and activation of immune responses. Delaying the innate recognition of the viral immunogenic signals during the lag phase probably leads to accumulation of self-immunogenic signals. In such a case, a rearrangement is likely to occur, where the noninfectious self dominates over infectious non-self, which seems to be less dangerous. In addition, there is certainly a progression of a strong inflammatory response in host tissues, which causes an increased need for regulation [51]. The data regarding the spectrum of AAbs in the sera of COVID-19 patients substantially correspond to this scheme. Antibodies against cardiolipin, which is an important component of the mitochondrial inner membrane, and AAbs to phospholipids, which constitute a key structural component of cell membranes, suggest that these AAbs play a role in housekeeping. Corresponding to the anti-cardiolipin antibodies, the identified anti- $\beta 2$-glycoprotein 1 , which is a multifunctional plasma protein binding cardiolipin, may confirm such a role for these AAbs in eliminating unwanted protein complexes. The antibodies against $52 \mathrm{kDa}$ SSA/Ro and $60 \mathrm{kDa}$ SSA/Ro ribonucleoproteins located in cytosol and nucleus, respectively, and antibodies against MDA5 (melanoma differentiationassociated protein 5) - one of the intracellular pattern recognition receptors, which in naïve situations interacts with the adaptor MAVS (mitochondrial antiviral signaling protein) and directly initiates transcription of the type I interferon genes-might be oriented to the complex of these intracellular proteins with viral RNA and further support the assignment of housekeeping functions to this group of AAbs. A regulatory function for AAbs against MDA5 is rather unlikely because the mechanism for antibody transition across the intact 
plasma membrane of the target cell is not yet known; their presence, rather, illustrates the housekeeping role of induced AAbs oriented to self-targets originating from damaged cells. COVID-19 shares a similar inflammatory immune response with autoinflammatory and autoimmune conditions induced by the flare up production of proinflammatory cytokines [52]. Thus, the antibody specificities induced by SARS-CoV-2 infection, having interferon, interleukin, and chemokine targets, are oriented to control the inflammatory response that is a dominant complication of COVID-19. The antibodies might have a different role against type 1 interferons. Type 1 interferons, through either the STAT1/STAT2 and IRF9 signaling pathway, activate the IFN-stimulated genes functionally associated with an antiviral response or act through the homodimer STAT1 or heterodimer CRKL/STAT5 to initiate the transcription of genes controlling immune responses and inflammation $[53,54]$. Other AAbs can contribute to the control of inflammation by preventing the manifestation of lymphokines and chemokines proinflammatory effect. The IL- 6 is a multipotent cytokine with strong proinflammatory orientation, GM-CSF activates at the genome inflammatory program, CXCL1 contributes to the processes of inflammation (through neutrophils activation), CCL2 also contributes to the inflammatory processes by activation of monocyte/macrophage infiltration, CCL15 is expressed only in the lungs by neutrophils and alveolar macrophages, and finally, CCL16 is a chemoattractant for monocytes and lymphocytes. The AAbs against these cytokines have already been detected in the sera of COVID-19 patients [52]. Therefore, we believe these natural AAbs have a regulatory role and as such represent an attempt to harmonize and control activated mechanisms of immune responsiveness. The natural AAbs might also have a regulatory function against MDA5. This protein, with two $\mathrm{N}$ terminal caspase activation and recruitment domains, upon activation by viral RNA binding, interacts with the adaptor mitochondrial antiviral signaling protein, which ultimately leads to transcription of the type I interferon genes [55]. In the case of the natural AAbs against MDA5 regulatory function, however, we would have to assume penetration of these antibodies into the cytosol of infected cells, which, according to current knowledge, is impossible under natural conditions.

Such AAbs specificities further support the notion that these autoantibodies are needed for the elimination of self-targets originating from damaged cells. Their role can also be supported by the fact that the new onset of autoantibodies positively correlates with the response to SARS-CoV-2 proteins [6], which suggests a balance between the response to infectious nonself (SARS-CoV-2) and noninfectious self (SARS-CoV-2 damaged cells).

To summarize our opinions as presented here, we hypothesize that the SARS-CoV-2 infection can induce the production of NAbs by interaction with pleural "responding" B1 cells during the lag phase of infection. These cells express the ACE2 receptors [56] and may be infected similarly to lung pneumocytes. The spectrum of NAbs specificities produced is dependent on the individual immune history and on the ontogenetic experience of the human body with microorganisms. The immediate immune status is further modulated by the status of the gut microbiota at the time of infection. Such individual experiences create a basic state of the instructed innate immune system [25,26], which controls, regulates, and enables the expression of all subsequent events of the innate as well as adaptive immune mechanisms. As SARS-CoV-2 replicates inside host cells, the products of the host cell-pathogen interaction are recognized by innate immune sensors and activate the mechanisms of innate immunity. The innate immune response is dominantly dependent on the induction of inflammation, which is a critical step that should be strictly regulated by controlling the inflammation inducers. AAbs constitute an effective regulatory tool that, along with regulatory cytokines, can control inflammation inducers based on products of the virus's devastating action on host tissues, regardless of whether they are of viral origin or are components or products of the host's own cells. SARS-CoV-2 infection is complicated by the fact that a considerable number of viral protein epitopes identical to the epitopes of human proteins exist $[48,57,58]$. If their immune recognition does in fact occur, then this fact may affect the production of AAbs, which can be produced both by memory B cells (trained immunity) and as a result of the adaptive immune response. 
Thus, molecular mimicry could be a real further, crucial step of the pathogenetic cascade initiated by SARS-CoV-2 infection and a reason for AAbs production. From all that is discussed above, we consider the production of AAbs during SARS-CoV-2 infection as a regulatory process and an attempt to re-establish homeostasis and not as a result of immune processes dysregulation. The production of AAbs seems nevertheless to be a double-edged sword that must be used properly under strict control; otherwise, it can cause severe health complications.

In conclusion, we would like to emphasize that we present this essay on host-pathogen interrelationships with the intent to open up discussions focused on the possible role of innate immune recognition and the subsequent innate immune response during SARSCoV-2 infection. The character of the first steps of mutual host-pathogen interactions may suggest the final processes of SARS-CoV-2 infection resolution. The analysis of some clinical data suggests that autoantibodies restricting the interaction of SARS-CoV-2 with the host cells expressing ACE2 may lead to some delayed severe complications occurring in affected patients $[59,60]$. SARS-CoV-2 significantly induces de novo production of autoantibodies [61], but whether they are the result of signals generated by the virus leading to immune disharmony or are an extreme tool to control homeostasis must by clarified by further clinical data and critical bioinformatic analyzes.

Author Contributions: A.M. and K.K. participated in the conceptualization, investigation, and writing of the original draft. All authors have read and agreed to the published version of the manuscript.

Funding: This study was supported by the grant MV-83962-1/OBVV-2020 from the Ministry of Interior of the Czech Republic.

Institutional Review Board Statement: Not applicable.

Informed Consent Statement: Not applicable.

Data Availability Statement: Not applicable.

Acknowledgments: The authors thank Irene Mac Allister (US Army Engineer and Research Development Center) for the critical reading of the manuscript.

Conflicts of Interest: The authors declare no conflict of interests.

\section{References}

1. Zhang, Y.; Xiao, M.; Zhang, S.; Xia, P.; Cao, W.; Jiang, W.; Chen, H.; Ding, X.; Zhao, H.; Zhang, H.; et al. Coagulopathy and Antiphospholipid Antibodies in Patients with Covid-19. N. Engl. J. Med. 2020, 382, e38. [CrossRef] [PubMed]

2. Zuo, Y.; Estes, S.K.; Gandhi, A.A.; Yalavarthi, S.; Ali, R.A.; Shi, H.; Sule, G.; Gockman, K.; Madison, J.A.; Zuo, M.; et al. Prothrombotic Antiphospholipid Antibodies in COVID-19. medRxiv 2020. [CrossRef]

3. Bastard, P.; Rosen, L.B.; Zhang, Q.; Michailidis, E.; Hoffmann, H.H.; Zhang, Y.; Dorgham, K.; Philippot, Q.; Rosain, J.; Béziat, V.; et al. Autoantibodies against Type I IFNs in Patients with Life-Threatening COVID-19. Science 2020, 370, 6515. [CrossRef] [PubMed]

4. Zhou, Y.; Han, T.; Chen, J.; Hou, C.; Hua, L.; He, S.; Guo, Y.; Zhang, S.; Wang, Y.; Yuan, J.; et al. Clinical and Autoimmune Characteristics of Severe and Critical Cases of COVID-19. Clin. Transl Sci. 2020, 13, 1077-1086. [CrossRef]

5. Wang, E.Y.; Mao, T.; Klein, J.; Dai, Y.; Huck, J.D.; Liu, F.; Zheng, N.S.; Zhou, T.; Israelow, B.; Wong, P.; et al. Diverse Functional Autoantibodies in Patients with COVID-19. medRxiv 2020. [CrossRef]

6. Chang, S.E.; Feng, A.; Meng, W.; Apostolidis, S.A.; Mack, E.; Artandi, M.; Barman, L.; Bennett, K.; Chakraborty, S.; Chang, I.; et al. New-Onset IgG Autoantibodies in Hospitalized Patients with COVID-19. medRxiv 2021. [CrossRef]

7. Pascolini, S.; Vannini, A.; Deleonardi, G.; Ciordinik, M.; Sensoli, A.; Carletti, I.; Veronesi, L.; Ricci, C.; Pronesti, A.; Mazzanti, L.; et al. COVID-19 and Immunological Dysregulation: Can Autoantibodies Be Useful? Clin. Transl. Sci. 2020. [CrossRef]

8. Tay, M.Z.; Poh, C.M.; Rénia, L.; MacAry, P.A.; Ng, L.F.P. The trinity of COVID-19: Immunity, inflammation and intervention. Nat. Rev. Immunol. 2020, 20, 363-374. [CrossRef]

9. Matz, H.; Munir, D.; Logue, J.; Dooley, H. The Immunoglobulins of Cartilaginous Fishes. Dev. Comp. Immunol. 2021, 115, 103873. [CrossRef] [PubMed]

10. Tyler, A. Agglutination of Sea-Urchin Eggs by Means of a Substance Extracted from the Eggs. Proc. Natl. Acad. Sci. USA 1940, 26, 249-256. [CrossRef]

11. Tyler, A. On Natural Auto-Antibodies as Evidenced by Anti-Venin in Serum and Liver Extract of the Gila Monster. Proc. Natl. Acad. Sci. USA 1946, 32, 195-201. [CrossRef] 
12. Boyden, S. Cellular recognition of foreign matter. Int. Rev. Exp. Pathol. 1963, 2, 311-356. [PubMed]

13. Boyden, S. Natural Antibodies and the Immune Response. Adv. Immunol. 1966, 5, 1-28. [CrossRef] [PubMed]

14. Asherson, G.L.; Rose, M.E. Autoantibody Production in Rabbits III. The Effect of Infection with Eimeria Stiedae and Its Relation to Natural Antibody. Immunology 1963, 6, 207-216. [PubMed]

15. Asherson, G.L.; Holborow, E.J. Autoantibody Production in Rabbits VII. Autoantibodies to Gut Produced by the Injection of Bacteria. Immunology 1966, 10, 161-167.

16. Hammarström, S.; Perlmann, P.; Gustafsson, B.E.; Lagercrantz, R. Autoantibodies to Colon in Germfree Rats Monocontaminated with Clostridium Difficile. J. Exp. Med. 1969, 129, 747-756. [CrossRef] [PubMed]

17. Kubelkova, K.; Hudcovic, T.; Kozakova, H.; Pejchal, J.; Macela, A. Early Infection-Induced Natural Antibody Response. Sci. Rep. 2021, 11, 1541. [CrossRef]

18. Havlasová, J.; Hernychová, L.; Halada, P.; Pellantová, V.; Krejsek, J.; Stulík, J.; Macela, A.; Jungblut, P.R.; Larsson, P.; Forsman, M. Mapping of Immunoreactive Antigens of Francisella Tularensis Live Vaccine Strain. Proteomics 2002, 2, 857-867. [CrossRef]

19. Havlasová, J.; Hernychová, L.; Brychta, M.; Hubálek, M.; Lenco, J.; Larsson, P.; Lundqvist, M.; Forsman, M.; Krocová, Z.; Stulík, J.; et al. Proteomic Analysis of Anti-Francisella Tularensis LVS Antibody Response in Murine Model of Tularemia. Proteomics 2005, 5, 2090-2103. [CrossRef]

20. Eyles, J.E.; Unal, B.; Hartley, M.G.; Newstead, S.L.; Flick-Smith, H.; Prior, J.L.; Oyston, P.C.; Randall, A.; Mu, Y.; Hirst, S.; et al. Immunodominant Francisella Tularensis Antigens Identified Using Proteome Microarray. Proteomics 2007, 7, $2172-2183$. [CrossRef] [PubMed]

21. Janovská, S.; Pávková, I.; Reichelová, M.; Hubáleka, M.; Stulík, J.; Macela, A. Proteomic Analysis of Antibody Response in a Case of Laboratory-Acquired Infection with Francisella Tularensis Subsp. Tularensis. Folia Microbiol. 2007, 52, 194-198. [CrossRef]

22. Janovská, S.; Pávková, I.; Hubálek, M.; Lenco, J.; Macela, A.; Stulík, J. Identification of Immunoreactive Antigens in Membrane Proteins Enriched Fraction from Francisella Tularensis LVS. Immunol. Lett. 2007, 108, 151-159. [CrossRef] [PubMed]

23. Baumgarth, N.; Waffarn, E.E.; Nguyen, T.T.T. Natural and Induced B-1 Cell Immunity to Infections Raises Questions of Nature versus Nurture. Ann. N. Y. Acad. Sci. 2015, 1362, 188-199. [CrossRef] [PubMed]

24. Schwartz, J.T.; Barker, J.H.; Long, M.E.; Kaufman, J.; McCracken, J.; Allen, L.-A.H. Natural IgM Mediates Complement-Dependent Uptake of Francisella Tularensis by Human Neutrophils via CR1 and CR3 in Nonimmune Serum. J. Immunol. 2012, 189, 3064-3077. [CrossRef]

25. Plzakova, L.; Krocova, Z.; Kubelkova, K.; Macela, A. Entry of Francisella Tularensis into Murine B Cells: The Role of B Cell Receptors and Complement Receptors. PLoS ONE 2015, 10, e0132571. [CrossRef]

26. Geier, H.; Celli, J. Phagocytic Receptors Dictate Phagosomal Escape and Intracellular Proliferation of Francisella Tularensis. Infect. Immun. 2011, 79, 2204-2214. [CrossRef]

27. Netea, M.G.; Quintin, J.; van der Meer, J.W. Trained Immunity: A Memory for Innate Host Defense. Cell Host Microbe 2011, 9 , 355-361. [CrossRef] [PubMed]

28. Netea, M.G.; Joosten, L.A.; Latz, E.; Mills, K.H.; Natoli, G.; Stunnenberg, H.G.; O’Neill, L.A.; Xavier, R.J. Trained Immunity: A Program of Innate Immune Memory in Health and Disease. Science 2016, 352, 6284. [CrossRef]

29. Netea, M.G.; Domínguez-Andrés, J.; Barreiro, L.B.; Chavakis, T.; Divangahi, M.; Fuchs, E.; Joosten, L.A.B.; van der Meer, J.W.; Mhlanga, M.M.; Mulder, W.J.M.; et al. Defining Trained Immunity and Its Role in Health and Disease. Nat. Rev. Immunol. 2020, 20, 375-388. [CrossRef] [PubMed]

30. Griffin, D.O.; Holodick, N.E.; Rothstein, T.L. Human B1 Cells in Umbilical Cord and Adult Peripheral Blood Express the Novel Phenotype CD20+ CD27+ CD43+ CD70-. J. Exp. Med. 2011, 208, 67-80, Erratum in 2011, 208, 871; Erratum in 2011, 208, 409; Erratum in 2011, 208, 67. [CrossRef]

31. Griffin, D.O.; Rothstein, T.L. Human b1 Cell Frequency: Isolation and Analysis of Human b1 Cells. Front. Immunol. 2012, 3, 122. [CrossRef]

32. Zhou, P.; Yang, X.-L.; Wang, X.-G.; Hu, B.; Zhang, L.; Zhang, W.; Si, H.-R.; Zhu, Y.; Li, B.; Huang, C.-L.; et al. A Pneumonia Outbreak Associated with a New Coronavirus of Probable Bat Origin. Nature 2020, 579, 270-273. [CrossRef]

33. Bourgonje, A.R.; Abdulle, A.E.; Timens, W.; Hillebrands, J.L.; Navis, G.J.; Gordijn, S.J.; Bolling, M.C.; Dijkstra, G.; Voors, A.A.; Osterhaus, A.D.; et al. Angiotensin-Converting Enzyme 2 (ACE2), SARS-CoV-2 and the Pathophysiology of Coronavirus Disease 2019 (COVID-19). J. Pathol. 2020, 251, 228-248. [CrossRef]

34. Wang, Q.; Zhang, Y.; Wu, L.; Niu, S.; Song, C.; Zhang, Z.; Lu, G.; Qiao, C.; Hu, Y.; Yuen, K.Y.; et al. Structural and Functional Basis of SARS-CoV-2 Entry by Using Human ACE2. Cell 2020, 181, 894-904.e9. [CrossRef] [PubMed]

35. Gheblawi, M.; Wang, K.; Viveiros, A.; Nguyen, Q.; Zhong, J.-C.; Turner, A.J.; Raizada, M.K.; Grant, M.B.; Oudit, G.Y. AngiotensinConverting Enzyme 2: SARS-CoV-2 Receptor and Regulator of the Renin-Angiotensin System. Circ. Res. 2020, 126. [CrossRef] [PubMed]

36. Mahmudpour, M.; Roozbeh, J.; Keshavarz, M.; Farrokhi, S.; Nabipour, I. COVID-19 Cytokine Storm: The Anger of Inflammation. Cytokine 2020, 133, 155151. [CrossRef]

37. Ragab, D.; Salah Eldin, H.; Taeimah, M.; Khattab, R.; Salem, R. The COVID-19 Cytokine Storm; What We Know So Far. Front. Immunol. 2020, 11. [CrossRef] [PubMed]

38. Ye, Q.; Wang, B.; Mao, J. The Pathogenesis and Treatment of the 'Cytokine Storm' in COVID-19. J. Infect. 2020, 80, 607-613. [CrossRef] [PubMed] 
39. Zhou, M.; Zhang, X.; Qu, J. Coronavirus Disease 2019 (COVID-19): A Clinical Update. Front. Med. 2020, 14, 126-135. [CrossRef]

40. Kubelkova, K.; Macela, A. Innate Immune Recognition: An Issue More Complex Than Expected. Front. Cell Infect. Microbiol. 2019, 9, 241. [CrossRef]

41. Wu, K.E.; Fazal, F.M.; Parker, K.R.; Zou, J.; Chang, H.Y. RNA-GPS Predicts SARS-CoV-2 RNA Residency to Host Mitochondria and Nucleolus. Cell Syst. 2020, 11, 102-108.e3. [CrossRef] [PubMed]

42. Jiang, H.W.; Zhang, H.N.; Meng, Q.F.; Xie, J.; Li, Y.; Chen, H.; Zheng, Y.X.; Wang, X.N.; Qi, H.; Zhang, J.; et al. SARS-CoV-2 Orf9b Suppresses Type I Interferon Responses by Targeting TOM70. Cell Mol. Immunol. 2020, 17, 998-1000. [CrossRef]

43. Battagello, D.S.; Dragunas, G.; Klein, M.O.; Ayub, A.L.P.; Velloso, F.J.; Correa, R.G. Unpuzzling COVID-19: Tissue-Related Signaling Pathways Associated with SARS-CoV-2 Infection and Transmission. Clin. Sci. 2020, 134, 2137-2160. [CrossRef]

44. Gurung, P.; Lukens, J.R.; Kanneganti, T.D. Mitochondria: Diversity in the Regulation of the NLRP3 Inflammasome. Trends Mol. Med. 2015, 21, 193-201. [CrossRef]

45. Burtscher, J.; Cappellano, G.; Omori, A.; Koshiba, T.; Millet, G.P. Mitochondria: In the Cross Fire of SARS-CoV-2 and Immunity. Science 2020, 23, 101631. [CrossRef] [PubMed]

46. Wood, E.; Hall, K.H.; Tate, W. Role of Mitochondria, Oxidative Stress and the Response to Antioxidants in Myalgic Encephalomyelitis/chronic Fatigue Syndrome: A Possible Approach to SARS-CoV-2 “Long-Haulers”? Chronic Dis. Transl. Med. 2020. [CrossRef]

47. Marino Gammazza, A.; Légaré, S.; Lo Bosco, G.; Fucarino, A.; Angileri, F.; Conway de Macario, E.; Macario, A.J.; Cappello, F. Human Molecular Chaperones Share with SARS-CoV-2 Antigenic Epitopes Potentially Capable of Eliciting Autoimmunity against Endothelial Cells: Possible Role of Molecular Mimicry in COVID-19. Cell Stress Chaperones 2020, 25, 737-741. [CrossRef]

48. Kanduc, D.; Shoenfeld, Y. Molecular Mimicry between SARS-CoV-2 Spike Glycoprotein and Mammalian Proteomes: Implications for the Vaccine. Immunol. Res. 2020, 68, 310-313. [CrossRef]

49. Lucchese, G.; Flöel, A. Molecular Mimicry between SARS-CoV-2 and Respiratory Pacemaker Neurons. Autoimmun. Rev. 2020, 19, 102556. [CrossRef]

50. Grifoni, A.; Weiskopf, D.; Ramirez, S.I.; Mateus, J.; Dan, J.M.; Moderbacher, C.R.; Rawlings, S.A.; Sutherland, A.; Premkumar, L.; Jadi, R.S.; et al. Targets of T Cell Responses to SARS-CoV-2 Coronavirus in Humans with COVID-19 Disease and Unexposed Individuals. Cell 2020, 181, 1489-1501.e15. [CrossRef]

51. Fu, Y.; Cheng, Y.; Wu, Y. Understanding SARS-CoV-2-Mediated Inflammatory Responses: From Mechanisms to Potential Therapeutic Tools. Virol. Sin. 2020, 35, 266-271. [CrossRef]

52. Mahevas, M.; Tran, V.T.; Roumier, M.; Chabrol, A.; Paule, R.; Guillaud, C.; Gallien, S.; Lepeule, R.; Szwebel, T.A.; Lescure, X.; et al. Autoinflammatory and autoimmune conditions at the crossroad of COVID-19. J. Autoimmun. 2020, 114, 102506. [CrossRef]

53. Platanias, L. Mechanisms of Type-I- and Type-II-Interferon-Mediated Signalling. Nat. Rev. Immunol. 2005, 5, 375-386. [CrossRef] [PubMed]

54. Chen, K.; Liu, J.; Cao, X. Regulation of Type I Interferon Signaling in Immunity and Inflammation: A Comprehensive Review. J. Autoimmun. 2017, 83, 1-11. [CrossRef]

55. Dias Junior, A.G.; Sampaio, N.G.; Rehwinkel, J. A Balancing Act: MDA5 in Antiviral Immunity and Autoinflammation. Trends Microbiol. 2019, 27, 75-85. [CrossRef]

56. Li, M.Y.; Li, L.; Zhang, Y.; Wang, X.S. Expression of the SARS-CoV-2 cell receptor gene ACE2 in a wide variety of human tissues. Infect. Dis. Poverty 2020, 9, 45. [CrossRef]

57. Kanduc, D. From Anti-SARS-CoV-2 Immune Responses to COVID-19 via Molecular Mimicry. Antibodies 2020, 9, 33. [CrossRef]

58. Cappello, F.; Gammazza, A.M.; Dieli, F.; Conway de Macario, E.; Macario, A.J. Does SARS-CoV-2 Trigger StressInducedAutoimmunity by Molecular Mimicry? A Hypothesis. J. Clin. Med. 2020, 9, 2038. [CrossRef]

59. Amiral, J.; Vissac, A.M.; Seghatchian, J. Covid-19, induced activation of hemostasis, and immune reactions: Can an auto-immune reaction contribute to the delayed severe complications observed in some patients? Transfus. Apher. Sci. 2020, 59, 102804. [CrossRef]

60. Townsend, A. Autoimmunity to ACE2 as a possible cause of tissue inflammation in Covid-19. Med. Hypotheses 2020, 144, 110043. [CrossRef]

61. Woodruff, M.C.; Ramonell, R.P.; Eun-Hyung Lee, F.; Sanz, I. Clinically identifiable autoreactivity is common in severe SARS-CoV-2 Infection. medRxiv 2020. [CrossRef] 